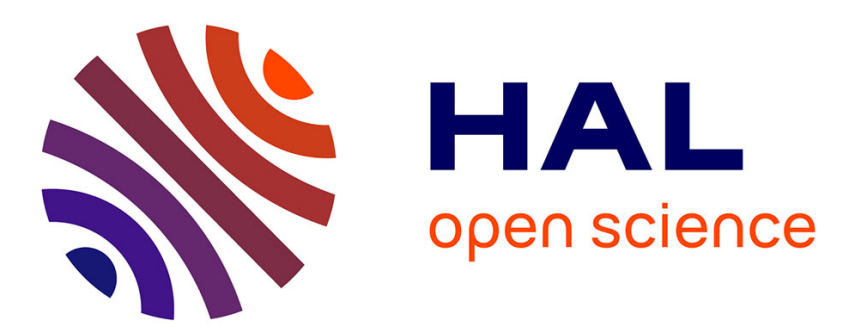

\title{
Euroscepticism under Margaret Thatcher and David Cameron: From Theory to Practice
}

\author{
Agnès Alexandre-Collier
}

\section{To cite this version:}

Agnès Alexandre-Collier. Euroscepticism under Margaret Thatcher and David Cameron: From Theory to Practice. Observatoire de la société britannique, 2015, The legacy of Thatcherism, 17, 10.4000/osb.1778 . halshs-01287011

\section{HAL Id: halshs-01287011 https://shs.hal.science/halshs-01287011}

Submitted on 14 Mar 2016

HAL is a multi-disciplinary open access archive for the deposit and dissemination of scientific research documents, whether they are published or not. The documents may come from teaching and research institutions in France or abroad, or from public or private research centers.
L'archive ouverte pluridisciplinaire HAL, est destinée au dépôt et à la diffusion de documents scientifiques de niveau recherche, publiés ou non, émanant des établissements d'enseignement et de recherche français ou étrangers, des laboratoires publics ou privés. 


\title{
Euroscepticism under Margaret Thatcher and David Cameron: From Theory to Practice
}

\author{
Agnès Alexandre-Collier
}

\begin{abstract}
Margaret Thatcher was often portrayed as the "spiritual mother" of Euroscepticism. But with hindsight, one can argue that Thatcher's Euroscepticism was actually limited to her vision of Europe and her divisive style. Over twenty years later, David Cameron's European policy, though inspired by Thatcher's Euroscepticism, is now based on a clear-cut Eurosceptic agenda which is nevertheless criticised for being more moderate than that of today's Eurosceptics.

This article will first argue that although Thatcher's European agenda could hardly be assessed as Eurosceptic as such, it paved the way for the radicalisation of Euroscepticism, not only as narrative but as a set of actual policies towards the EU, to such an extent that it changed the dynamics of the Conservative Party's structure. The article will then show how practical Euroscepticism under David Cameron has come to permeate party leadership in terms of agenda-setting and party management, and propose tentative explanations for Eurosceptic radicalisation in the party. Finally, it will be suggested that over and above institutional, constitutional and ideological environmental causes, usually put forward as affecting Conservative attitudes to European integration today, more relevant explanations can be found in party organisational changes.
\end{abstract}

\section{Key words}

Margaret Thatcher, David Cameron, Euroscepticism, Conservative Party. leadership. 


\section{Introduction}

The pivotal role of Margaret Thatcher in Conservative party politics and history is such that the question of her legacy is still at the heart of political and academic debate, reactivated since her death on 8 April 2013. One month before his election as party leader, David Cameron summarised the embarrassment in which her legacy has plunged his party since she left office in November 1990 in these terms: "I'm certainly a big Thatcher fan, but I don't know whether that makes me a Thatcherite" (Cameron, BBC's newsnight, 17 November 2005, quoted in Bale, 2010: 384). Since the 1970s, scientific literature has had to wrestle with the nature of social and economic changes brought about by Thatcherism, though scholars appeared to agree on the extent and depth of the transformations it had generated. Disagreement has centered mainly on the fundamental restructuring and transformation of the British State. As early as 1979, the expression "authoritarian populism" was debated, initially by Stuart Hall, followed by other scholars (Hall \& Jacques, 1983). Since then, two aspects of Thatcher's legacy have been most often posited: on the one hand, the extent to which Thatcher was deemed to have shaped an economic neo-liberal model which was preserved and even furthered by her successors; on the other hand, the impact of her vision of a liberal and intergovernmental Europe of independent sovereign states on the British narrative of Euroscepticism.

Some scholars have combined both dimensions to define Thatcherism as an "aggressive postimperial reassertion of a liberal conception of Britain as a free market society" (Gifford, 2014b: 80). Thus, in demonstrating the continuous strength and impact of Thatcherism, the concept of legacy is itself illuminating, shedding light retrospectively on the bequeather (Thatcher) and also on the legatee (Cameron), two periods which will be compared in this article in relation to the British debate on European integration.

The very notion of Euroscepticism, first as a new word devised by the British Press (Szczerbiak \& Taggart, 2008, vol. 2: 240) then as a social science concept constantly debated by scholars (Szczerbiak \& Taggart, 2008, vol. 1: 3-7), is regularly invoked as a shortcut to simplify the complexity of Britain's relationship with the EU. From the 1990s onwards, there has indeed been an endless terminological debate about the notion of Euroscepticism. A consensus seems however to have been reached with Szczerbiak and Taggart's authoritative definitions. Unlike hard Euroscepticism "which might be defined as principled opposition to the project of European integration as embodied in the EU, in other words, based on the ceding or transfer of powers to supranational institutions such as the EU", soft Euroscepticism suggests that "there is not a principled objection to the European integration project of transferring powers to a supranational body such as the EU, but there is opposition to the EU's current or future planned trajectory based on the future extension of competencies that the EU is planning to make" (Szczerbiak \& Taggart, 2008, vol. 2: 247-248). In the British case, Euroscepticism was often closely associated with the Conservative Party and Thatcherism in particular, though it also spread within the Labour Party (Forster, 2002). As Gifford argued, "Euroscepticism became fundamental to protecting the Thatcher legacy" (Gifford, 2014a: 519).

Also underlying this connection was the view that Euroscepticism had become a clear-cut position on European integration which could be easily identified with Margaret Thatcher herself. From then on, it ceased to be some sort of vague feeling of opposition to European integration but an engrained attitude which could potentially expand into a movement in itself. One could even argue that Euroscepticism being institutionalised became an organic component of the pluralism within the Conservative Party.

To demonstrate this point, this article will first seek to expose a paradox in Margaret Thatcher's agenda, arguing that although her European agenda could hardly be assessed as Eurosceptic as such, it paved the way for a radicalisation of Euroscepticism not only as narrative but as a set of actual policies in relation to the EU, to the point of changing the dynamics of the Conservative Party's structure. The article will then show how Euroscepticism under David Cameron has come to permeate party leadership in terms of agenda-setting and party management and propose tentative explanations for the Eurosceptic radicalisation within the party. The article will suggest that over and above institutional, constitutional and ideological environmental causes, usually put forward as affecting Conservative 
attitudes to European integration, more relevant explanations, overlooked by scholars, can be found in party organisational changes.

\section{The enigma of Thatcher's European agenda}

To understand the issue of Margaret Thatcher's European legacy, it is essential to have a clear vision of her European agenda, which, with hindsight, has always been a complex question. Firstly, her agenda only became clearer at the end of her last term, that is after the 1988 Bruges speech when she finally expounded her vision, eventually felt as being at odds with the official position on Europe of the party, still dubbed the "party of Europe" (Alexandre-Collier, 2002a). Secondly, the very issue of her European agenda is multi-layered, containing as it does two levels of interpretation: on the one hand, a symbolic / rhetorical level can be noted when her vision of Europe is referred to in more abstract terms; on the other hand, there is a political level when her actions and actual policies are considered. The complexity of Thatcher's European agenda could be explained by an unprecedented discrepancy between the two levels, to such an extent that there was even talk of a "schizophrenic attitude to the European project" (Daddow, 2013: 217) or, in other words, a dichotomy between theory and practice which makes Thatcher's European agenda still very difficult to decipher.

Arguably, her vision of Europe outlined in the Bruges speech in 1988 was quite clearly that of a liberal, intergovernmental Europe, in which Britain could remain a free and independent country. Furthermore, Gifford explained how this vision was constructed on a number of oppositions between Britain and Europe: "European bureaucracy and political formalism versus British pragmatism and democracy; British free trade liberalism versus European protectionism; British globalism versus narrow Europeanism and British political stability versus European instability" (Gifford, 2014b: 97). Thatcher's rhetorical Euroscepticism was also substantiated by her diplomatic style, well illustrated by her attitude at the Fontainebleau Summit in 1984 when she famously negotiated a rebate on the British contribution to the EU budget. More significantly, it was revealed by her determination to oppose membership of the Exchange Rate Mechanism (ERM) of the European Monetary System, at all costs, at least until October 1990, a decision which alienated some of the members of her Cabinet including Geoffrey Howe who eventually resigned.

In the meantime, the reality of her actions and policies was fundamentally different, as illustrated by several examples. In 1986, she signed the Single European Act, drafted by the European Commissioner Lord Cockfield who had been one of her ministers. She later wrote in her memoirs: "I was pleased with what had been achieved. We were on course for the Single Market by 1992. I had to make relatively few compromises as regards wording; I had surrendered no important interest; I had to place a reservation on just one aspect of social policy in the Treaty" (Thatcher, 1993: 555), putting all the blame on Lord Cockfield for his inconsistency: "Unfortunately," she argued, "he tended to disregard the larger questions of politics - constitutional sovereignty, national sentiment and the promptings of liberty. He was the prisoner as well as the master of his subject. It was all too easy for him, therefore, to go native and to move from deregulating the market to reregulating it under the rubric of harmonization" (Thatcher, 1993: 547). She truly believed, as Hugo Young suggested, that the Single European Act was "Thatcherism on a European scale" (Young, 1998: 333) and by focusing on the economic dimension, she underestimated the institutional mechanisms that would be necessary to promote common policies in a wider range of areas. In addition, even though she had initially opposed membership of the ERM, she finally agreed to the principle of entry, as divisions in her Cabinet made her resistance eventually untenable and forced her to capitulate under the persuasive alliance of Douglas Hurd, Foreign Secretary and John Major, her new Chancellor of the Exchequer (Gifford, 2014b: 98).

Building on Szczerbiak and Taggart's definitions of Euroscepticism, the comparison between Thatcher's vision and determination with the reality of her European policies challenges the very idea of Thatcher's so-called "soft" Euroscepticism which, this article argues, was eventually more a question of style than of substance (Alexandre-Collier \& Avril, 2013: 33-35). With hindsight, it is clear that her 
Eurosceptic legacy has more to do with ideas than policies and that her views on Europe have been gradually built up since her demise, to the point of creating the political myth that she has become (Fontana \& Parsons, 2015). If one describes Euroscepticism not only as being reluctant to go along with European integration but also as a form of opposition to the idea itself, ranging from moderate opposition to some aspects of European integration (soft) to outright hostility to Britain's membership of the EEC (hard), the label hardly applies to Margaret Thatcher. If one understands Euroscepticism as a euphemism for opposition to the EU, which is certainly the closest to what it actually means today, the truth is that it was only after Thatcher left office that she became a Eurosceptic as such and that Thatcherism became synonymous with Euroscepticism, and it was also only after her departure that Euroscepticism developed. Much has been written about the ratification of the Maastricht Treaty in 1992-93 (Alexandre-Collier, 2002b; Baker et al., 1993 a, 1993b, 1994, 1995, 1998, 2008; Forster, 2002; Gifford, 2014b). This episode was indeed the 'watershed' moment (Forster, 2002: 8) when Euroscepticism was gradually to become an organised movement both in and outside Parliament (Usherwood, 2002; Gifford, 2014 a \& b), with for example the emergence of the Bruges group, described as "one of the most important guardians of the Thatcher shrine" (Vinen, 2009: 230). From both the Thatcher and post-Thatcher periods, the term Eurosceptic has come to refer not only to an attitude but also to a form of parliamentary behaviour (Alexandre-Collier, 2002b) and, indeed, to a movement in its own right.

\section{Cameron's practical Euroscepticism}

Today, relevant similarities can be found between David Cameron's and Margaret Thatcher's approaches to the EU. But these similarities have more to do with the rhetoric used by both leaders and its divisive impact on the parliamentary party. The Bloomberg speech delivered by David Cameron in January 2013 is clearly a perfect example of the mark left by Thatcher's vision of Europe when he advocates: "a flexible, adaptable and open EU", arguing that "We come to the EU with a frame of mind that is more practical than emotional", an echo of the Bruges speech "The community is not an end in itself. Nor is it an institutional device to be constantly modified according to the dictates of some abstract intellectual concept".

Party divisions are also a common denominator, as pluralism has always been an intrinsic feature of the Conservative parliamentary party. Divisions on the European issue have come to be seen as a deeply engrained yet fluctuating phenomenon (Alexandre-Collier, 2010: 27-45; Lynch \& Whitaker, 2013b). Although the party's agenda has changed radically since the 1980s, MPs' perception today of party tensions on Europe as being generated by Cameron's attitude, is a situation that both leaders have experienced. The difference, though, is that Cameron is viewed as being too moderate compared with the rest of the parliamentary party, whereas Thatcher was viewed as too radical. While Margaret Thatcher's position generated discontent among the pro-European members of her Cabinet and led to Geoffrey Howe's resignation, David Cameron's agenda triggered negative reactions from the most Eurosceptic elements on the Conservative back benches, the first example being that of David Nuttall, a newly elected Conservative MP. He introduced a petition demanding a referendum on Britain's membership of the EU, which eventually led to an unprecedented rebellion of 81 Conservative MPs in October 2011, 49 of whom had been elected in 2010 (Gifford, 2014b; Lynch et Whitaker, 2013a).

The comparison between Thatcher and Cameron, however, ends here. Differences between their attitudes to European integration are far more significant than the traces of Thatcherism still to be detected in Cameron's rhetoric. First of all, the parliamentary party has changed radically since 1990. Thirteen years in opposition paved the way for a complete generational renewal (Criddle, 2010) with the election of younger and more Eurosceptic MPs (Heppell, 2013) who "regard Euroscepticism as a given rather than a touchstone and (...) admire Thatcher without worshipping her" (Bale, 2010: 379). As a generation who for the most part grew up under Thatcher, the majority of MPs elected in 2010 are familiar with nothing else but the party's history of internal passions and frictions over the EU. As Bale and Gruber recently argued, "the Tories' strategy on the question of EU integration has evolved into a drama of its own" (Gruber \& Bale, 2014: 214). As already shown, the 'watershed' moment (Forster, 2008: 8) was the 
ratification of the Maastricht Treaty in 1992-93, under the premiership of John Major, and the setting up of political, economic and monetary union. From then on, the party has been so divided that Conservative tensions on European integration have almost become a textbook case.

When the Conservative Party was elected in May 2010 and formed a coalition government with the Liberal Democrats, the party's European agenda was, as a result, radically different from what it had been in the 1980s and 1990s. At that time, the main bone of contention was the prospect of political, economic and monetary Union leading presumably to a federal union - or the "F-Word" - rejected outright by Conservative Eurosceptics (Alexandre-Collier 2002a: 82). A climax had been reached in 2001 when the party in opposition objected to the pound joining the eurozone officially and permanently (Alexandre-Collier, 2010: 27-45). Today, membership of the EU has become the main divisive issue with the prospect of a referendum by $2017^{1}$. Since David Cameron's election as party leader in December 2005, the Conservatives have launched a series of initiatives and policies representing a clear turning point in the party's European strategy. One example is the decision to leave the European People's Party in the European Parliament in June 2009 and to set up a new group known as the European Conservatives and Reformists (ECR) together with the Czech and Polish Conservative parties, a move sometimes criticised as verging on populist (Alexandre-Collier, 2010: 7677). A second example is David Cameron's refusal to join the European Stability Mechanism and Euro Plus Pact, and the fact that he did not sign the Treaty known as the "fiscal compact". In Brussels, the Prime Minister justified his bold decision by declaring: "Margaret Thatcher never vetoed a treaty - I vetoed a treaty upstairs on the eighth floor of this building" (Dominiczak \& Waterfield, 2014). A third example is to be found with the $2010 \mathrm{EU}$ Bill which became the basis for the largest rebellion ever by Conservatives on Europe, even though it contained three commitments which could have been seen as significant Eurosceptic moves: "first, the referendum lock which required that any future treaties transferring national powers to European level be subject to a referendum; second, significant transfers of power without any treaty change, so called 'ratchet clauses', may also be subject to a referendum; third, a sovereignty clause" (attempting to state the supremacy of British Parliament with regard to EU law) (Gifford, 2014b: 156; for further analysis, see also Gifford 2014b: 155-170).

The EU agenda of the present government indicates a major shift from what could be seen as theoretical Euroscepticism to practical Euroscepticism. As will be argued later, this means not only nurturing the seeds which Margaret Thatcher had planted only in the very last years of her Premiership but going even further than anything that she could ever have imagined. The result is that today socalled Euroscepticism as an attitude to European integration has become the party's official EU stance. But if since Maastricht the word Eurosceptic had come to mean a form of parliamentary behaviour with reference to parliamentary rebels (Alexandre-Collier, 2002b), the meaning is now totally different as today's so-called Eurosceptics - or rebels - are clearly anti-EU, while what are known as the "Eurorealists" are more comparable with yesterday's Eurosceptics.

\section{Explaining practical Euroscepticism}

Explaining the spread of Euroscepticism in the Conservative party leadership requires a rapid but necessary foray into sociological theory so as to avoid cultural and political clichés. Leaving aside the "agency" approach to political leadership, which explains leaders' choices as being guided only by their individual desires, and which therefore runs the risk of providing simplistic psychological explanations, we posit that with political leaders being heavily dependent on "structures" ${ }^{2}$, the recent institutional and political structural changes in the UK shed light on the rapid development of Euroscepticism in but also around David Cameron and the shift from theoretical to practical

1 The referendum will be effectively held after a period of renegotiation with the EU and if the Conservatives win an overall majority at the May 2015 general election.

2 On the commonly used structure/agency duality, see for example Turner, 2006: 357-358. 
Euroscepticism since the 1980s. In line with the neo-institutionalist approach, whereby institutions constrain the elites' preferences and actions, we contend that various kinds of institutional pressures at all levels (supra, national but also sub-national) have converged towards the idea that the UK's institutional landscape has considerably changed. From this theoretical perspective, both external and contextual factors can be advanced to explain the surge of practical Euroscepticism.

As in the 1980s, the European Union, as an intricate institutional entity, remains difficult to decipher. Not only is it still an "unidentified political object", as Jacques Delors argued in 1989, but it is also a moving target. Arguably, the 2008 financial crisis has radically changed perceptions, so that Brexit (British exit), which was still taboo in the 1990s, has today become a realistic option with opinion polls showing public opinion to be divided on the issue ${ }^{3}$. Furthermore, the spread of Euroscepticism can be explained by a network of structural changes in the UK, which can be described as constitutional, institutional and party systemic. With regard to constitutional and institutional changes, the principle of parliamentary sovereignty has been under increasing pressure from both European integration and devolution, which should be conceived as interrelated processes. The result has been an extensive debate on the integrity of the UK as a nation-state. In addition, multi-level governance as a result of European integration and devolution has had a major impact on the subsequent weakening of Westminster in terms of decision-making and the need, first expressed by New Labour's government, to empower individuals and bring them closer to the locus of power. Creating devolved assemblies or consulting people directly became the main instruments of this constitutional agenda. From then on, the recurrent use of referenda has substantiated this constitutional evolution. Since Tony Blair and his buzzword of empowerment, the practice of power has clearly changed, with Britain's parliamentary democracy no longer appearing to be incompatible with tools of direct democracy. The New Labour governments thus opened a cycle which Cameron has been eager to continue, with the referendum on Alternative Voting in May 2011, on Scottish independence on 18 September 2014 and the future referendum on EU membership by 2017, distancing himself totally from Thatcher's denunciation in 1975 of the referendum as, quoting Clement Attlee, a "splendid weapon for dictators and demagogues" ${ }^{4}$. This new practice of government is in line with an increasing tendency to externalise the debate (Usherwood, 2002) in the case of divisive issues, while empowering voters and supporters in the Blairite tradition.

Changes in the party system also provide another structural explanation: the party system is more fragmented today (Cowley, 2011), as illustrated by the government status of the Liberal Democrats and the rise of UKIP, both of which could also be seen as relevant factors to account for the spread of Euroscepticism. The presence of the Liberal Democrats in the coalition government has certainly caused resentment in Conservative ranks. But more importantly, the growing popularity of UKIP has created a new ideological environment since this party now represents a direct threat to the Conservative Party, not necessarily in terms of votes (because of the First-Past-The-Post system) but because more Conservative MPs might now consider defecting to UKIP, following the examples of Douglas Carswell, on 28 August 2014, and Mark Reckless, on 27 September 2014 (Lynch \& Whitaker, 2013a; Ford \& Goodwin, 2014).

In addition to these structural changes, a new approach should be considered to account for this evolution by examining the way the internal organisation of the Conservative Party has also radically changed over recent years. Although scientific literature seems to plead for a more holistic approach to Euroscepticism by treating it as an independent variable (Vasilopoulou, 2013), this article argues that the study of Euroscepticism as a variable which remains nevertheless highly dependent on party competition and structure, provides, a closer analysis and understanding of present-day Conservative Euroscepticism and the actual impact of the Thatcherite legacy on the party's EU agenda.

3 While an opinion poll conducted by Opinium/The Observer on 4-7 November 2014 showed that $40 \%$ would be in favour of staying in, $43 \%$ against and $17 \%$ still unsure, later opinion polls conducted in early 2015 show that more than $50 \%$ would be in favour of staying in (57\% compared with $21 \%$ against and $17 \%$ unsure, according to a YouGov/Sun poll conducted on 22 and 23 February 2015).

4 Margaret Thatcher, House of Commons speech, Hansard HC 888/304-17, 11 March 1975. 
We contend that party organisational changes may offer a new and fruitful perspective to explain the shift from theoretical (under Thatcher) to practical Euroscepticism (under Cameron). This perspective provides strong arguments to explain not only the spread of Euroscepticism but how in Britain a new form of populism has come to permeate the whole Conservative party agenda and structure (Mudde \& Kaltwasser, 2012; Rosanvallon, 2011). Although this question of the temptation of populism in Cameron's style of leadership has already been discussed elsewhere (Higgins, 2013; Alexandre-Collier, 2015a), it remains an issue worthy of further reflexion. The radical changes in terms of party management and organisational reforms should be examined more closely from the perspective of the cartel party thesis (Katz \& Mair, 1995, 1997, 2009) suggesting a process of transformation which combines depoliticisation and professionalisation comparable with what has been at work in the Conservative Party. Organisational changes are not new, dating back to William Hague's reforms introduced in 1998 (Hague, 1997). These reforms concerned mainly the leadership election, with the introduction of a postal ballot for party members. With a view to democratising party organisation (Katz, 2001) and promoting inclusiveness, the reforms included the participation of party members in the leadership contest and the multiplication of focus groups and internal referenda to give them more sway. It also provided the party with a full constitution around which the three components of the party (parliamentary, professional and volunteer) could unite under the auspices of a new overarching party board with only 5 members elected by the National Convention. Commentators noted how these organisational changes only served to reveal the continuing authority of a hidden oligarchy behind the facade of enhanced democratisation (Kelly, 2003: 102-103). Others further argued that the 1998 reforms represented a shift in the party's balance of powers (Bale \& Turner, 2012), with the leader propelled to the top of a huge structure codified by the party constitution (Webb, 2000) and the apparent "bottom-up" strategies only serving to galvanise the "top-down" mentality style presiding over the party (Kelly, 2003: 102).

In capitalising on these reforms, David Cameron extended them even further and thus paved the way for an even more radical shift in the party balance of powers, with a leader who is now more dependent on the party's rank-and-file and grassroots. From this perspective, changes in the leadership election are particularly enlightening. Under Thatcher and since 1965, when the leadership election was democratised to encompass the MPs' votes in the process, a leader's survival had depended only on MPs: in November 1990 Thatcher herself lost the first round of voting by only 4 votes meaning that she did not get the majority required plus $15 \%$. To some extent, although the leader was no longer "chosen" but was elected by MPs, this famous example is still revealing of the then overwhelming power of MPs, as the structure was still based on the oligarchic model (Michels, 1915, 1968) inherited from the pre-1965 period, of the "magic circle", following a "chain of responsibility" (McKenzie 1955: 588) from the leader, the MPs to the voters (Webb, 1994). It was later revealed that in the run-up to the 1990 leadership contest, MPs had not been sufficiently canvassed (Bale, 2010: 27, 29) and the responsibility for this strategic error was often placed on one person: Peter Morrison, the Prime Minister's Private Parliamentary Secretary and Chairman of the 1922 Committee, the Conservative backbenchers' organisation. Margaret Thatcher wrote that "unfortunately, the same quality of serene optimism which made Peter so effective at cheering us all up was not necessarily so suitable for calculating the intentions of that most slippery of electorates - Conservative MPs" (Thatcher, 1993: 837). Norman Lamont, then Chief Secretary to the Treasury, even suggested that MPs' independence was treated like a protected territory and that, given his determination not to interfere and his overconfidence, Morrison's unhelpfulness may even have been intentional: "Several times, I rang Peter Morrison, her Campaign Manager, MP for Chester, and offered to call any wavering backbenchers. Trying to get names from bim was like extracting blood from a stone" (Lamont, 1999: 10) (see also Clark, 1999[1993]: 354-355).

In 1998, the election of the leader was further democratised, including a final postal ballot by all members of the party. This was a major change which signalled the end of a form of backbench domination over party organisation, though MPs retained key prerogatives, such as the right to remove a leader through a vote of confidence (Alderman, 1999: 268). Cameron benefitted from the new rules of the leadership election, as he was himself eventually chosen by party members while MPs were more 
divided between him and David Davis (Alexandre-Collier, 2010: 17). This reform clearly changed the balance of power in the party by making the leader more sensitive to the grassroots' needs and wishes and therefore more vulnerable to them, thus exposing the whole party to the risk of populism. But David Cameron then went further and extended organisational reforms to the way parliamentary candidates are selected, introducing two innovative devices intended to make the party organisation more inclusive and democratic: the priority list or "A-list" in 2006 (including at least 50\% of women and ethnic minorities) (McIlveen, 2009; Hill, 2013) and open primaries, where the ballot is open to any voter regardless of their party preferences and which were organised as early as 2003, before his election as party leader, but then considerably extended after 2005 to over a hundred constituencies. Two types of open primaries were introduced: primary meetings and all-postal open primaries. Since 2003, primary meetings had already been organised in more than a hundred constituencies (Criddle, 2010: 315) but only three all-postal primaries were introduced, first in Totnes and Gosport in $2009^{5}$ (with significant turnouts of $24.5 \%$ and $17.7 \%$ for Totnes and Gosport), following the MPs' expenses scandals of May, and then in Rochester and Strood in 2014, thus projecting an image of internal democratisation which does not necessarily correspond with reality (Alexandre-Collier 2015b). In their model of the cartel party, Katz and Mair had already suggested that future party transformations, necessary to overcome the inevitable collapse in party membership and party dealignment (Dalton \& Wattenberg, 2002), would require innovative strategies but result in blurring the boundaries between members and non-members (Katz \& Mair 1995, 1997 \& 2009). Katz's thesis of candidate selection as applied to the cartel party model indeed posited that by creating a direct relation between voters and candidates, open primaries undermine the influence of sub-units such as local party associations, and alter the distribution of power, but also create an illusion of democracy with voters empowered at the expense of party members, and party leadership closely controlling the whole process (Katz, 2001). The actual result has indeed been more centralisation around the leader who effectively controls the whole process and this enables him to bypass party intermediaries in order to gain more direct access to the grassroots. Based on the assumption that these grassroots are more Eurosceptic, Euroscepticism, as a consequence, has come to permeate the whole party structure, from bottom to top, with party leaders and MPs responding, in return, to this grassroots' pressure. More than simply proving Eurosceptic radicalisation, party organisational changes therefore illustrate the way in which the practice of power has changed, with a leader more inclined to please the grassroots when faced with the threat of voters turning to UKIP in the event of the party failing to deliver on Europe. The new rules for candidate selection reveal the new face of a party leadership which is less impervious to grassroots' pressure (voters and public opinion), at the expense of party members, and is perhaps more sensitive to the risk of populism, with a leader also more willing to yield to this pressure when threatened by internal divisions (Europe) or external challengers (UKIP) (Alexandre-Collier, 2015a \& b).

\section{Conclusion}

To some extent, David Cameron has now reached far beyond Margaret Thatcher's expectations, fulfilling or rather implementing her dreams. With a referendum on Brexit, Cameron may offer a softer version of what most so-called Eurosceptics now advocate. Yet, the likelihood of his campaigning for Brexit in the future referendum, though excluded for the time being, would distance him even further from the Thatcherite legacy regarding the continuum of Euroscepticism.

Compelling explanations are to be found in the network of institutional and party systemic factors which account for both the spread of Europeanisation and subsequent Euroscepticism at national level. From the Thatcher years up to the present time, it is easy to measure the impact of the constitutional and institutional changes brought about by European integration. But as far as the

5 Since then, there has been just one all-postal open primary in Rochester and Strood, to select the new prospective candidate for the Conservative Party in the by-election of 20 November 2014 following the defection of Conservative MP Mark Reckless to UKIP. 
Conservative Party itself is concerned, the spread of Euroscepticism, following on from Thatcher's rhetorical position but also as a phenomenon in itself, distinct from the set of policies she promoted or defended, also stems from radical changes in the balance of power between the various components of the party's organisation. Still powerful, the leader is at the top of a pyramid, reminiscent of McKenzie's oligarchic description. Yet the conditions of his/her ascension have changed, as has their capacity to respond to this evolution: while Margaret Thatcher's fate depended solely on the parliamentary party, David Cameron is now more receptive to grassroots pressure and more sensitive to populism. As one of its major effects, the spread of Euroscepticism can indeed be studied as indicative of how much the party has changed after Thatcher. Conservative MPs are now much bolder and more independent of their leader, but also more dependent than ever on their voters, to the extent of being tempted by populism. Party organisational changes have therefore paved the way for Euroscepticism to permeate the whole party structure, with the party leadership now being urged to respond more emotively to the temptation of populism, far less cautiously in fact than Margaret Thatcher.

\section{Works Cited}

Alderman, K. (1999) "Revision of leadership procedures in the Conservative Party", Parliamentary Affairs, vol. 52, n 2, 260-274.

Alexandre-Collier A. (2002a) La Grande-Bretagne eurosceptique? L'Europe dans le débat politique britannique, Nantes: Editions du Temps.

Alexandre-Collier A. (2002b) "Le phénomène eurosceptique au sein du parti conservateur britannique", Politique Européenne, $\mathrm{n}^{\circ}$ 6, 53-73.

Alexandre-Collier, A. (2010) Les habits neufs de David Cameron. Les conservateurs britanniques (1990-2010), Paris: Presses de Sciences Po.

Alexandre-Collier, A. et Avril, E. (2013) Les partis politiques en Grande-Bretagne, Paris: Armand Colin.

Alexandre-Collier, A. (2015a) "The temptation of populism in David Cameron's style of leadership", in

Alexandre-Collier, A. \& Vergniolle de Chantal, F. (eds), Leadership and Uncertainty Management in Politics:

Leaders, Followers and Constraints in Western Democracies, Basingstoke: Palgrave Macmillan.

Alexandre-Collier, A. (2015b) "The Open Garden of Politics? The Conservative Leadership's

Management of Open Primaries for Candidate Selection", UK Political Studies Association Annual

Conference, Sheffield, 30 March - 1 April 2015, unpublished paper.

Baker D., Gamble A., Ludlam S. (1993a) "Whips or Scorpions? The Maastricht vote and the Conservative Party", Parliamentary Affairs, vol. 46, n 2,151-166.

Baker D., Gamble A., Ludlam S. (1993b) "1846...1906...1996 ? Conservative splits and European integration", The Political Quarterly, vol. 64, $\mathrm{n}^{\circ}$ 4, 420-434.

Baker D., Gamble A., Ludlam S. (1994) "The Parliamentary Siege of Maastricht 1993: Conservative Divisions and British Ratification", Parliamentary Affairs, vol. 47, n 1, 37-60.

Baker D., Fountain I., Gamble A., Ludlam S. (1995) "Backbench Conservative Attitudes to European Integration", Political Quarterly, vol. 66, $\mathrm{n}^{\circ}$ 2, 221-233.

Baker D., Seawright D. (eds.) (1998) Britain For and Against Europe. British Politics and the Question of

European integration, Oxford: Clarendon Press.

Bale, T. (2010), The Conservative Party: from Thatcher to Cameron, Cambridge: Polity.

Bale, T. \& Turner, E. (2012) "Modernisation in small steps? Comparing the organisational reforms of the British Conservative Party and the German CDU", PSA Paper.

Clark, A. (1999[1993]), Diaries, London: Phoenix Giants.

Cowley, P. (2011) "Political Parties and the British Party System", in Richard Heffernan, Philip Cowley

\& Colin Hay, Developments in British Politics 9, London: Palgrave Macmillan, 2011, p. 91-112.

Criddle, B.(2010) "More Diverse, Yet More Uniform: MPs and Candidates", in Kavanagh D. \& Cowley

P., The British General Election of 2010, Basingstoke: Palgrave Macmillan, p. 306-329.

Daddow, O. (2013) "Margaret Thatcher, Tony Blair and the Eurosceptic Tradition in Britain", The British Journal of Politics and International Relations, Vol. 15, 210-227. 
Dalton, R. \& Wattenberg, M. (2002) Parties without Partisans. Political Change in Advanced Industrial Democracies, Oxford: Oxford University Press.

Dominiczak, P. \& Watefield, B. (2014) "Cameron styles himself as the heir to Thatcher", The Daily Telegraph, 27 June.

Fontana, C. \& Parsons, C. (2015) "'One Woman's Prejudice': Did Margaret Thatcher Cause Britain's Anti-Europeanism?", Journal of Common Market Studies, Vol. 53, n¹, 89-105.

Ford, R. \& Goodwin, M. (2014) Revolt on the Right. Explaining support for the radical right in Britain, London \& New York: Routledge.

Forster A. (2002) Euroscepticism in Contemporary British Politics. Opposition to Europe in the British Conservative and Labour Parties since 1945, London \& New York: Routledge.

Gifford, C. (2014a) "The People Against Europe: The Eurosceptic Challenge to the United Kingdom's Coalition Government", Journal of Common Market Studies, Vol 52, $\mathrm{n}^{\circ}$ 3, 512-528.

Gifford, C. (2014b [2008]), The making of Eurosceptic Britain, Farnham: Ashgate.

Gruber, O. \& Bale, T. (2014) "And it's good night Vienna. How (not) to deal with the populist, radical right: The Conservatives, UKIP and some lessons from the heartland", British Politics, vol. 9, n³, 237 254.

Hague, W. (1997) A Fresh Future for the Conservative Party, London: Conservative Central Office. Hall, S. \& Jacques, M. (1983) (eds.) The Politics of Thatcherism, London: Lawrence and Wishart. Heppell, T. \& Hill, M. (2009) "Transcending Thatcherism? Ideology and the Conservative Party Leadership Mandate of David Cameron", The Political Quarterly, vol. 80, n 3, p. 388-399.

Heppell, T., (2013) "Cameron and Liberal Conservatism: Attitudes within the Parliamentary Conservative Party and Conservative Ministers", The British Journal of Politics and International Relations, vol. 15, n³, 340-361.

Higgins, M. (2013), "Governmentality, populism and empowerment. David Cameron's rhetoric of the big society", in Scullion, R., Gerodimos, R., Jackson, D., Lilleker, D. G. (dir.) The Media, Participation and Empowerment, Abingdon: Routledge.

Hill, M. (2013) "Arrogant Posh Boys? The Social Composition of the Parliamentary Conservative Party and the Effects of Cameron's 'A'-list", The Political Quarterly, Vol. 84, n 1, 80-89.

Katz, R. \& Mair, P. (1995) "Changing Models of Party Organization and Party Democracy: the Emergence of the Cartel Party", Party Politics, vol. 1, n 1, 5-28.

Katz, R. \& Mair, P. (1997), "Party Organisation, Party Democracy and the Emergence of the Cartel Party", in Mair, P. Party System Change: Approaches and Interpretations, Oxford: Oxford University Press, p. 93-119.

Katz, R. \& Mair, P. (2009) "The Cartel Party Thesis: A Restatement", Perspective on Politics, vol. 7, $\mathrm{n}^{\circ} 4$, 753-766.

Katz, R. (2001) "The Problem of Candidate Selection and Models of Party Democracy", Party Politics, Vol. 7, n³, 277-296.

Kelly, R. (2003), "Organisational reform and the extra-parliamentary party", in Garnett, M. \& Lynch, P. (eds.), The Conservatives in Crisis. The Tories after 1997, Manchester: Manchester University Press, p. 82106.

Lamont, N. (1999) In Office, London: Little, Brown and Company.

Lynch P. \& Whitaker, R. (2013a) "Rivalry on the right: The Conservatives, the UK Independence Party (UKIP) and the EU issue", British Politics, Vol. 8, n 3, p. 285-312.

Lynch, P. \& Whitaker, R. (2013b) "Where There is Discord, Can they Bring Harmony? Managing Intraparty Dissent on European Integration in the Conservative Party", The British Journal of Politics and International Relations, vol. 15, 317-339.

McIlveen, R. (2009) "Ladies of the Right: An Interim Analysis of the A-List", Journal of Elections, Public Opinion and Parties, Vol. 19, n 2, 147-157.

McKenzie, R. T. (1955) British political parties. The distribution of power within the Conservative and Labour Parties, London: William Heinemann Ltd.

Michels, R. $(1915,1968)$ Political Parties: A Sociological Study of the Oligarchic Tendencies of Modern 
Democarcies, New York: The Free Press.

Mudde, C. \& Kaltwasser, C. R. (2012) (eds.) Populism in Europe and the Americas. Threat or Corrective for Democracy, Cambridge: Cambridge University Press.

Rosanvallon, P. (2011), "Penser le populisme", Leçon inaugurale au Collège de France, 18 juillet 2011. <http://www.laviedesidees.fr/Penser-le-populisme.html> Accessed on 10 April 2015.

Szczerbiak A. \& Taggart P. (2008) Opposing Europe? The Comparative Party Politics of Euroscepticism, vol. 1 \& 2, Oxford: Oxford University Press.

Thatcher, M. (1993) The Downing Street Years, London: HarperCollins Publishers.

Turner, J. E. (2006) (ed.) Handbook of Sociological Theory, New York: Springer.

Usherwood, S. (2002) "Opposition to the European Union in the UK: The dilemma of public opinion and party management", Government and Opposition, vol. 37, n² 2, 211-230.

Vasilopoulou S. (2013) "Continuity and change in the study of Euroscepticism: Plus ça change?", Journal of Common Market Studies, vol. 51, n¹,153-168.

Vinen, R. (2009) Thatcher's Britain. The Politics and Social Upheaval of the 1980s, London: Simon \&

Schuster.

Webb, P. (1994) "Party Organisational Change in Britain: The Iron Law of Centralization?", in Katz, R. \& Mair, P. (eds.) How Parties Organize: Change and Adaptation in Party Organizations in Western Democracies, London: Sage, p. 109-133.

Webb, P. (2000) The Modern British Party System, London: Sage.

Young, H. (1998) This Blessed Plot. Britain and Europe from Churchill to Blair, London: Macmillan. 